\title{
Pneumatic displacement without tissue plasminogen activator in premacular subhyaloid hemorrhage
}

\author{
Rumita S.Kadarisman
}

\begin{abstract}
Abstrak
Untuk mengetahui effektivitas dan keamanan injeksi intravitreal gas Sulfur Heksaflorida (SF6) tanpa tissue Plasminogen Activator (tPA) pada perdarahan subhialoid di premakula, 5 mata dari 5 pasen dimasukkan dalam penelitian ini. Setelah parasentesis cairan akuos, $0.3 \mathrm{ml}$ gas sulfur hexafluoride murni disuntikkan intravitreal dan penderita diharuskan mempertahankan posisi muka kebawah selama 5 hari.. Foto fundus dibuat pre injeksi,pada 1 hari dan 7 hari pasca injeksi. Perdarahan subhialoid bergeser pada $4 / 5$ (80\%) mata dengan lama perdarahan subhialoid kurang dari 2 minggu. Tajam penglihatan pre-operatif pada ke-lima mata adalah hitung jari, dan mengalami perbaikan pasca-operatif pada 4/5 (80\%) mata dalam 3 hari sampai 7 hari.. Tajam penglihatan berkisar antara 6/20 hingga 6/6. Penyakit sistemik yang mendasari, terdiri dari hiperkoagulasi pada 1 pasien, diabetes mellitus pada 2 pasien, hipertensi pada 1 pasien dan tidak ditemukan pada 1 pasien. Komplikasi.akibat tindakan tidak ditemukan pada semua mata yang diinjeksi. Sebagai kesimpulan, injeksi gas SF6 tanpa penggunaan tPA ke dalam vitreus mampu menggeser perdarahan subhialoid, bila dilakukan dalam 14 hari, dan dapat menghasilkan perbaikan tajam penglihatan yang cepat. Tindakan ini terbukti aman. (Med J Indones 2007; 16:104-7)
\end{abstract}

\begin{abstract}
To assess the efficacy and safety of intravitreal injection of Sulfur Hexafluoride (SF6) gas without the use of tissue Plasminogen Activator (tPA) in premacular Subhyaloid Hemorrhage ( SHH ), 5 eyes of 5 patients with premacular SHH were enrolled. After performing paracentesis of the anterior chamber, $0.3 \mathrm{ml}$ pure SF6 gas was injected through pars plana with a 30 gauge needle. Facedown position was maintained for 5 days. Subhyaloid Hemorrhage was displaced in 4/5 (80\%) eyes with a duration of SHH less than 2 weeks. The pre-injection visual acuity of all 5 eyes was finger counting and improved in 4/5 (80\%) eyes within 3 days to 7 days post-injection to 6/20 - 6/6. The underlying disease was hypercoagulation in 1 patient, diabetes mellitus in 2 patients, hypertension in 1 patient and unknown in 1 patient. No complications were encountered. In conclusion, SF6 gas injected into the vitreous without the use of tPA, can displace SHH if performed within 14 days of duration, and results in rapid visual recovery. This procedure is proven to be safe. (Med J Indones 2007; 16:104-7)
\end{abstract}

Keywords: subhyaloid hemorrhage, pneumatic displacement, sulfur hexafluoride gas

Subhyaloid hemorrhage (SHH) refers to blood located between the internal limiting membrane and posterior hyaloid. The hyaloid is attached in the region surrounding the hemorrhage. The hemorrhage appears with a shape of air fluid level and it completely obscures the underlying fundus details. Premacular SHH can lead to sudden and severe visual loss. It may occur in retinal vascular disorders such as proliferative diabetic retinopathy (PDR), branch retinal vein occlusion, macroaneurysm, and age related macular degeneration. It also may occur in hematological disorders such as leukemia and chemotherapy induced pancytopenia or after retinal vascular rupture associated with physical exertion (valsalva retinopathy). ${ }^{1}$

Vitreoretina Clinic, Department of Ophthalmology, Faculty of Medicine, University of Indonesia/Dr. Cipto Mangunkusumo Hospital, Jakarta, Indonesia
Spontaneous resorbtion of the hemorrhage entrapped in subhyaloid space can be awaited, but may cause permanent impairment of vision due to pigment macular changes Formation of epiretinal membranes and toxic damage to the retina due prolonged contact with hemoglobin and iron also causes irreversible visual loss. ${ }^{1-2}$

A variety of therapeutic approaches have been developed to treat SHH. NdYAG laser and pars plana vitrectomy has been reported to promote visual recovery, but these forms of treatment also has its disadvantages, causing complications. ${ }^{1,3,5}$

Another kind of treatment, pneumatic displacement with sulfur hexafluoride (SF6) and tPA for SHH was first reported by Schmitz et al. and demonstrated effective treatment ${ }^{4}$. Their initial experience suggested an anatomic success and facilitated visual improve- 
ment with no complications. Koh et $\mathrm{al}^{6}$ performed the same procedure with Perfluoropropane $(\mathrm{C} 3 \mathrm{~F} 8)$ gas for SHH. Their study showed a good result with complete displacement of the blood and an improvement on vision after two months. According to them, this procedure is technically simple and the rate of serious complication appears to be acceptably low. But the use of tPA is sometimes still controversial with a complication of vitreous hemorrhage, besides being costly. Pneumatic displacement with gas, without tPA is an alternative method in the treatment of $\mathrm{SHH}$ which was reported in one case by Park in 2004 .

\section{METHODS}

Five eyes of 5 patients were enrolled. After a comprehensive ocular examination a color photograph was taken. The patients were consulted to an Internist for further evaluation of the underlying disease. The procedure was performed in the operating room, after controlling the blood pressure and blood sugar. After instillation of topical anaesthetic eye drops, an antisepsis of the ocular area was performed, and an eye speculum was applied. Paracentesis of the anterior chamber was carried out, with immediate injection of $0.3 \mathrm{ml}$ pure SF6 gas with a 30 gauge needle, through the pars plana in the inferior quadrant.

Topical antibiotic eye drops was instilled and the eye was then patched. Oral antibiotics was prescribed. Prone position was recommended until 3-5 days postoperatively. On the first, and 3 to 14 postoperative day, displacement of the $\mathrm{SHH}$, visual acuity and complications consisting of endophthalmitis, vitreous hemorrhage, retinal tears, retinal detachment and increased intraocular pressure were evaluated.
Outcome measured were the duration of visual loss corresponding to the duration of premacular $\mathrm{SHH}$, the underlying disease, visual acuity improvement at 3 days to 7 days post- injection, and complications.

\section{RESULTS}

The characteristics of 5 eyes with pneumatic displacement in premacular SHH as seen in table 1, shows patients age ranged between 23 - 80 yo, consisting of 4 females and one male. The underlying disease was hypercoagulation in 1 patient, diabetes mellitus in 2 patients, hypertension in 1 patient, while no abnormality was found in 1 patient who was 28 years old.

The duration of visual loss was less than 14 days in 4 patients and more than 14 days in 1 patient. Displacement of the hemorrhage was successful in all 4 patients with a duration of less than 14 days, and was not successful in one in eye with a duration of SHH more than 14 days. The visual acuity improved within 1 day to 7 days post injection, from 1-6 m CF to $6 / 20-6 / 6$ in 4 eyes with successful displacement. Complications were not encountered.

\section{CASE REPORT}

\section{Case 1}

A 46 yo female complained of sudden visual loss in the left eye since 10 days previously. Visual acuity before operation was $6 \mathrm{~m}$ counting fingers (CF), one day after injection became $6 / 15$ and after 3 days improved to $6 / 6$ (figure 1). Hypercoagulation was found to be the underlying factor and treatment was given. No complications occurred.

Table 1. Characteristics of five eyes with pneumatic displacement without tPA in premacular SHH

\begin{tabular}{|c|c|c|c|c|c|c|}
\hline \multirow{3}{*}{$\begin{array}{c}\text { Sex/Age } \\
\text { (yo) }\end{array}$} & \multirow[t]{3}{*}{ Underlying Factor } & \multirow{3}{*}{$\begin{array}{c}\text { Duration } \\
\text { (days) }\end{array}$} & \multicolumn{3}{|c|}{ Visual Acuity } & \multirow[t]{3}{*}{ Complications } \\
\hline & & & Pre-inejction & 1 day & 3-7 days & \\
\hline & & & & Post inj & Post inj & \\
\hline 1. F/ 42 & Hypercoagulation & 10 & $6 \mathrm{~m} \mathrm{CF}$ & $6 / 15$ & $6 / 6$ & none \\
\hline 2. F / 46 & DM & 7 & $3 \mathrm{~m} \mathrm{CF}$ & $6 / 30$ & $6 / 10$ & none \\
\hline 3. $\mathrm{M} / 80$ & $\mathrm{DM}$ & 2 & $5 \mathrm{~m} \mathrm{CF}$ & $6 / 12$ & $6 / 12$ & none \\
\hline 4. F / 49 & Hypertension & 7 & $1 \mathrm{~m} \mathrm{CF}$ & $6 \mathrm{~m} \mathrm{CF}$ & $6 / 20$ & none \\
\hline 5. F / 23 & NA & $>14$ & $1 \mathrm{~m} \mathrm{CF}$ & $1 \mathrm{~m} \mathrm{CF}$ & $1 \mathrm{~m} \mathrm{CF}$ & none \\
\hline
\end{tabular}

$\mathrm{SHH}=$ subhyaloid hemorrhage, $\mathrm{DM}=$ diabetes mellitus, $\mathrm{CF}=$ counting fingers, $\mathrm{NA}=$ no abnormality 


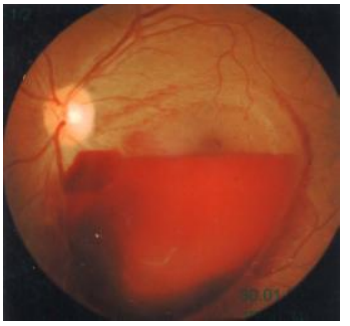

a

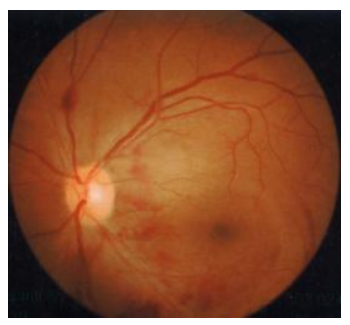

c

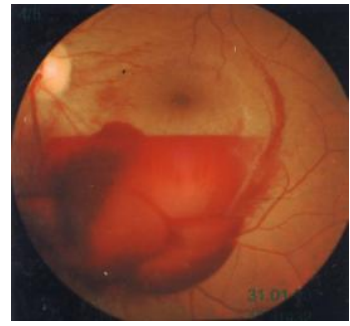

b

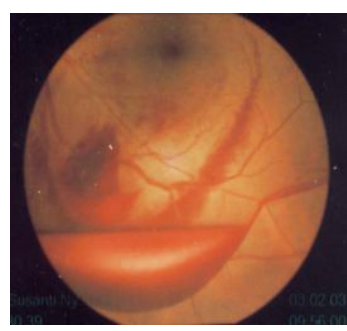

d

Figure 1 a. pre-injection with visual acuity of $6 m C F$. $b$. one day post injection, the hemorrhage is displaced inferiorly and visual acuity becomes $6 / 15$. c. and $d$. three days post-injection the hemorrhage is completely displaced from the macula and visual acuity improved to $6 / 6$

\section{Case 2}

A 58 yo female complained of sudden visual loss in the right eye since 7 days and visual acuity was $3 \mathrm{~m} \mathrm{CF}$ (figure 2). One day after injection part of the hemorrhage was displaced with visual acuity of $6 / 30$ and after 7 days. Most of the hemorrhage was more inferiorly displaced and visual acuity improved to 6/10 (figure 2). The underlying factor was diabetes mellitus, which was already being treated. No complications occured.

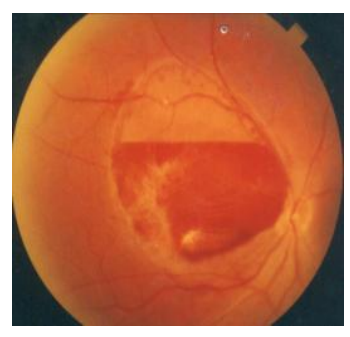

a

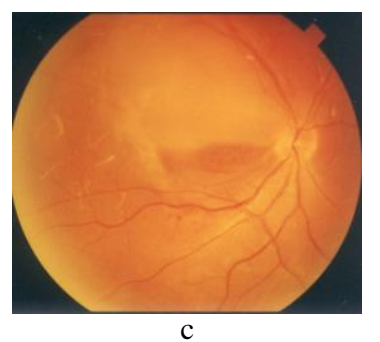

Figure 2. a. before injection with visual acuity of $3 \mathrm{mCF}$. $b$. one day post injection with visual acuity of $6 / 30$. c. seven days post injection with visual acuity of $6 / 10$

\section{Case 3}

A 23 yo female complained of sudden visual loss in the right eye since more than 14 days with a visual acuity of $1 \mathrm{~m} \mathrm{CF}$ (figure 3 ). One week after injection, no displacement of the hemorrhage was noted, and visual acuity remained $1 \mathrm{~m} \mathrm{CF}$ (figure 3 ). No systemic abnormality was found and no complications occurred.

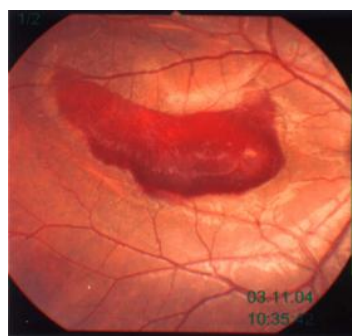

Figure 3. before injection with visual acuity of $1 \mathrm{~m} \mathrm{CF}$ which remained until 7 days post

\section{DISCUSSION}

Subhyaloid hemorrhage may develop in vascular disorders, such as diabetes mellitus as seen in case 2 and case 3 , and hypertensive retinopathy as is seen in case 4. This condition may also occur in hematologic disorders like leukemia and chemotherapy, pancytopenia, but no one has reported hypercoagulation as seen in case 1 , as an underlying disease. Since the retinal vasculature in hypercoagulation patients is still normal, the patient with hypercoagulation achieved better vision even only 3 days after operation, compared to those cases with diabetes mellitus and hypertension.

In cases of subhyaloid hemorrhage, intraocular gas injection with tPA, laser photo disruption with NdYag laser, and pars plana vitrectomy can be performed to promote an early visual recovery. ${ }^{3-6}$ Laser photodisruption is the most simple treatment. It will result in drainage of the hemorrhage into the vitreous. However, there is a possibility of retinal damage. In addition, it might be ineffective in cases with a thick posterior cortical vitreous and media opacity such as cataract and vitreous opacity, as reported by Park. He used SF6 gas without tPA to displace SHH and the hemorrhage dispersed into the vitreous. ${ }^{2}$

An intraocular gas injection in combination with tPA is also a simple and effective procedure. In this treatment modality, tPA might induce posterior vitreous detachment and fibrinolysis to promote blood displacement and clearance. However, the mechanical compression effect of the intraocular gas alone can 
cause the subhyaloid spreading of a subhyaloid hemorrhage and can complete the posterior vitreous detachment initiated by the original hemorrhage. The subhyaloid hemorrhage can then disperse into the vitreous cavity and disappear effectively. This effect can be obtained with the use of a short acting gas like SF6 gas. Therefore, tPA my not be necessary for patients with a relatively new SHH with a duration of less than 14 days as shown in case 1-4. Hemorrhages presenting more than 14 days becomes solid, may not be displaced as in case 5 and might need tPA. Pars plana vitrectomy which is indicated for SHH with breakthrough of hemorrhage into the vitreous is the most invasive option and has the possibility of several surgical complications. ${ }^{1,3,5}$

Complications that might occur in intravitreal injection consists of endophthalmitis elevated intraocular pressure, retinal or choroidal hemorrhage, and retinal break formation, and these did not occur in any of the eyes.

\section{CONCLUSIONS}

Intravitreal injection of a small quantity of SF6 gas without tPA showed to be an effective and safe treatment in displacing premacular SHH occurring less than 14 days and resulted in improvement of visual acuity in $4 / 5(80 \%)$ eyes without any complications, 3 days to 7 days after injection.. Displacement of the hemorrhage failed and subsequently visual acuity remained poor in one eye with premacular $\mathrm{SHH}$ of more than 14 days.

\section{REFERENCES}

1. Elliot P, Michael SL, Gary WA. Proliferative Diabetic Retinopathy. Principles and technique of treatment. In: Ryan SJ, editor. Retina 4 th ed. Volume 3. St Louis: Mosby:2006.p 2413-49.

2. Park SW, Seo MS. Subhyaloid hemorrhage treated with Sf6 gas injection Ophthalmic surgery, laser and Imaging 2004;35:4-6

3. Ahmadabi M, Lashay A, Karkhaneh R, et al. Nd: YAG laser application in premacular subhyaloid hemorrhage. Arch Iranian Med. 2004;7:206-9

4. Schmitz K, Kreutzer B, Hitzer S, et al. Therapy of Subhyaloidal hemorrhage by intravitreal application of rTPA and SF6 gas. Br J Ophthalmol. 2000;84:1324-8.

5. Adel B, Israel A, Friedman Z. Dense subhyaloid hemorrhage or subinternal limiting membrane hemorrhage in the macula treated by Nd: YAG laser. Arch Ophthalmol. 1998;116:1542-6.

6. Koh HJ, Kim SH, Lee DC, Kwon OW. Treatment of subhyaloid hemorrhage with intravitreal tissue plasminogen activator and $\mathrm{C} 3 \mathrm{~F} 8$ gas injection. $\mathrm{Br} \mathrm{J}$ Ophtahlmol 2000; 84:1329-32. 